\title{
A Quantum Leap in Energy Efficiency to Put the Sustainable Development Goals in Closer Reach
}

Puig, Daniel; Farrell, Timothy Clifford; Moner-Girona, Magda

Published in:

Global Policy

Link to article, DOI:

$10.1111 / 1758-5899.12574$

Publication date:

2018

Document Version

Peer reviewed version

Link back to DTU Orbit

Citation (APA):

Puig, D., Farrell, T. C., \& Moner-Girona, M. (2018). A Quantum Leap in Energy Efficiency to Put the Sustainable Development Goals in Closer Reach. Global Policy, 9(3), 429-431. https://doi.org/10.1111/1758-5899.12574

\section{General rights}

Copyright and moral rights for the publications made accessible in the public portal are retained by the authors and/or other copyright owners and it is a condition of accessing publications that users recognise and abide by the legal requirements associated with these rights.

- Users may download and print one copy of any publication from the public portal for the purpose of private study or research.

- You may not further distribute the material or use it for any profit-making activity or commercial gain

- You may freely distribute the URL identifying the publication in the public portal 


\title{
A quantum leap in energy efficiency to put the Sustainable Development Goals in closer reach
}

\author{
Practitioner Commentary
}

\section{Short title}

Energy efficiency and the SDGs

\section{Author information \\ Daniel Puig $(*)$}

Technical University of Denmark

Daniel Puig is a Senior Advisor at the Technical University of Denmark, where he works on nationallevel scenarios in support of climate-change policy planning. Prior to this, Daniel worked the United Nations Environment Programme's Division of Technology, Industry and Economics, and in the environmental economics department of an international consultancy company.

$\left({ }^{*}\right)$ corresponding author

\section{Timothy Clifford Farrell}

Australian Research Council

Tim Farrell recently joined the Australian Research Council. Prior to this, Tim worked as Senior Advisor at the Copenhagen Centre on Energy Efficiency, supporting the United Nations' Sustainable Energy for All initiative. Before joining the Copenhagen Centre, Tim was implementing energy efficiency policies and programs in Australia, Southeast Asia and the Pacific.

\section{Magda Moner-Girona}

\section{European Commission's Joint Research Centre}

Magda Moner-Girona is a researcher focused on techno-economic analyses of policies aimed at enhancing the deployment of renewable energy in developing countries, and promoting energyrelated sustainable development goals. She has worked at the United Nation Environment Programme, the European Commission's Joint Research Centre, and the University of California at Berkeley. 


\section{Abstract}

Targeted improvements in the way energy is transformed, distributed and used can accelerate progress toward achieving the United Nations' Sustainable Development Goals. Compared to a situation in which no indicators are defined and monitored, tracking progress through indicators would make it easier to reap the full developmental benefits associated with improvements in energy efficiency. We call upon G20 leaders to adopt SDG-specific energy-efficiency indicators, with a view to ultimately accelerating progress toward achieving the United Nations' Sustainable Development Goals.

\section{Manuscript}

The traditional, energy sector-centred, rationale for energy efficiency gains is threefold: increasing energy security, improving access to modern forms of energy, and reducing emissions of global warming gases (GEA 2012).

Notwithstanding these benefits, which are critical to the energy sector, public policy efforts aimed to improve energy efficiency are increasingly being justified against a much broader array of benefits. Prominent examples include enhanced local air quality, expanded employment opportunities, reduced public sector expenditure, or improved trade balances, among many others (Puig and Farrell 2014). Two estimates, drawn from a larger set published by the International Energy Agency, illustrate this point (OECD/IEA 2014):

- Every 1 million euro invested in energy efficiency measures has a job creation potential that ranges from 8 to 27 job-years.

- When health and well-being impacts are included in the calculation, energy efficiency retrofits in buildings have benefit-cost ratios as high as 4:1.

Against this background, it is increasingly accepted that targeted improvements in the way energy is transformed, distributed and used can accelerate progress toward achieving the United Nations' Sustainable Development Goals (SDGs) (UNEP 2016). ${ }^{1}$ For example, energy efficiency retrofits in buildings (such as energy-efficient heating, ventilation and air conditioning systems) can contribute to achieving SDG3 on healthy lives and well-being. Similarly, energy-efficient machinery (from industrial motors and pumps, to boiler and heating systems) can contribute to achieving SDG8 on sustained, inclusive and sustainable economic growth.

While the performance of actions to achieve the SDGs is monitored (UN-DESA 2017), the extent to which these actions take advantage of the developmental benefits associated with energy efficiency improvements is not systematically tracked. Certainly, SDG7 (on affordable and clean energy) has raised the profile of energy efficiency with regard to energy security, access to modern forms of energy, and mitigation of greenhouse-gas emissions. ${ }^{2}$ However, the broader, non-energy-related benefits are not being measured and, as a result, the true benefits of energy efficiency are being underestimated even in SDG7, and much more so in other SDGs. For those additional benefits to be realised more effectively and swiftly, a monitoring programme including energy efficiency-related indicators is needed. Such programme would highlight that current investment levels in energy efficiency are far from commensurate with the benefits arising from improvements in the way energy is transformed, distributed and used: additional financial support is needed, notably to develop baselines and collect data on programme and project performance. 
Compared to a situation in which no indicators are defined and monitored (Locke et al. 1981), tracking progress through indicators would make it easier for decision makers to identify both barriers to, and enablers of, energy efficiency improvements, with a view to ultimately increasing energy efficiency. In practice, both processes go hand-in-hand: the more one knows about barriers and enablers, the easier it is to define indicators, the calculation of which increases one's knowledge about barriers and enablers.

Fortunately, a great deal of experience has been amassed over the past two decades concerning both barriers to, and enablers of, energy efficiency improvements (Puig and Farrell 2014). The following list of lessons learnt, which is not meant to be comprehensive, is provided for illustrative purposes. $^{3}$

- Barriers. Economic disincentives are common hurdles that most sectors continue to face (for example, in the form of subsidised energy prices, caps on the financial incentives offered to entice participation in an energy efficiency programme, or high up-front costs for certain technologies). Design failures are of especially significance in energy efficiency programmes targeting highly competitive sectors (for example, perceived lack of privacy and concerns over data protection, or lack of non-compliance penalties). Limited technical capacities, especially in low-income countries, continue to hamper all types of energy efficiency programmes (for example, through the lack of testing and certification bodies, or the lack of experience with energy efficiency programmes on the part of governmental staff). Administrative inconsistencies are of relevance mostly in large countries, with devolved sub-national administrations (for example, in the form of conflicting requirements across administrative boundaries, insufficient or ineffective coordination within different layers of government, or unduly burdensome administrative requirements).

- Enablers. Economic barriers have been prevented through ex-ante economic analyses, the results of which are used to fine-tune the design of energy efficiency programmes. These analyses have helped identify the type and size of the economic incentive required to compensate companies financially, while taking economies of scale into account, and to reduce risks. Design shortcomings have in several instances been overcome through clear enrolment procedures for potential beneficiaries of energy efficiency programmes, the inclusion of mechanisms to regularly evaluate (and improve) performance, or the inclusion of peer-pressure mechanisms to foster compliance. Technical capacity gaps are typically bridged through training programmes of different kinds, an area in which development finance institutions have gained substantial experience over the years. In the instances where they have been used, binding regulatory requirements and stringent enforcement procedures have proved to be a key drive of energy efficiency improvements.

Simply stated, enough is known about the barriers to, and enablers of, energy efficiency improvements to underpin the development of detailed energy efficiency indicators. Tracking progress toward energy efficiency at the level of individual SDGs can strengthen efforts to implement the SDGs (Table 1). We argue that specialised United Nations agencies - for example, the Food and Agriculture Organization, for SDG2, or the World Health Organization, for SDG3 - are well placed to centralise data collection efforts, which would require limited expansion.

On 23-24 May 2018, G20 leaders will meet in Copenhagen (Denmark), in the context of the Clean Energy Ministerial. ${ }^{4}$ Increasing the efficiency with which societies transform, distribute and use energy will be one of the main discussion topics. For the ninth year in a row, energy efficiency will find its space in the G2O leaders agenda, which is most often dominated by global policy issues such 
as the resilience of the global financial system, or the fight against terrorism. Such strong political emphasis on energy efficiency is grounded in the growing realisation that, as outlined above, investments in energy efficiency support development. ${ }^{5}$ In light of the account provided in the previous paragraphs, we call upon G20 leaders to adopt SDG-specific energy-efficiency indicators. 


\begin{tabular}{|c|c|c|}
\hline $\begin{array}{l}\text { SDG targets, the achievement of which can be facilitated by } \\
\text { improvements in energy efficiency }\end{array}$ & Reasons why energy efficiency is relevant to efforts to meet the target & References \\
\hline $\begin{array}{l}\text { Target 2.3. By } 2030 \text { double the agricultural productivity and the incomes } \\
\text { of small-scale food producers, particularly women, indigenous peoples, } \\
\text { family farmers, pastoralists and fishers, including through secure and } \\
\text { equal access to land, other productive resources and inputs, knowledge, } \\
\text { financial services, markets, and opportunities for value addition and } \\
\text { non-farm employment. }\end{array}$ & $\begin{array}{l}\text { Achieving this target will require mechanisation. The higher the } \\
\text { efficiency with which this mechanisation is accomplished, the lower the } \\
\text { fuel costs by unit of output, or the more output achievable for the same } \\
\text { amount of fuel expenditure. }\end{array}$ & $\begin{array}{l}\text { Gellings, C.W. (2009). Energy efficiency in agricultural equipment. In } \\
\text { Efficient use and conservation of energy (pp. 106-122) Oxford. EOLSS } \\
\text { Publishers Co. Ltd. }\end{array}$ \\
\hline $\begin{array}{l}\text { Target 2.a. Increase investment, including through enhanced } \\
\text { international cooperation, in rural infrastructure, agricultural research } \\
\text { and extension services, technology development, and plant and livestock } \\
\text { gene banks to enhance agricultural productive capacity in developing } \\
\text { countries, in particular in least developed countries. }\end{array}$ & $\begin{array}{l}\text { Optimising rural infrastructure, such as irrigation systems, distributed } \\
\text { electricity networks, and food storage facilities, requires consideration of } \\
\text { system-wide energy efficiency improvement. These energy-efficient } \\
\text { choices can optimise the benefits of the infrastructure per unit of fuel } \\
\text { expenditure. }\end{array}$ & $\begin{array}{l}\text { Gellings, C.W. (2009). Energy efficiency in pumping and irrigation } \\
\text { systems. In Efficient use and conservation of energy (pp. 95-105) Oxford. } \\
\text { EOLSS Publishers Co. Ltd. }\end{array}$ \\
\hline $\begin{array}{l}\text { Target 3.6. By 2020, halve the number of global deaths and injuries from } \\
\text { road traffic accidents. }\end{array}$ & $\begin{array}{l}\text { Compared to traditional technologies, light-emitting diode (LED) } \\
\text { technologies provide more output for the same amount of energy. } \\
\text { Reliance on LED makes it possible to expand the coverage of street } \\
\text { lighting, thus contributing to improved road safety. }\end{array}$ & $\begin{array}{l}\text { Beale, S. (2016). Energy efficiency in road operations and management. } \\
\text { Conference of European Directors of Roads. Brussels. }\end{array}$ \\
\hline $\begin{array}{l}\text { Target 3.9. By 2030, substantially reduce the number of deaths and } \\
\text { illnesses from hazardous chemicals and air, water and soil pollution and } \\
\text { contamination. }\end{array}$ & $\begin{array}{l}\text { Supply- and demand-side energy efficiency can help reduce the need for } \\
\text { additional generation, thus lowering emissions of local air pollutants } \\
\text { associated with the combustion of certain fuels. }\end{array}$ & $\begin{array}{l}\text { GEA (2012). Global Energy Assessment - Toward a Sustainable Future. } \\
\text { Cambridge University Press, and the International Institute for Applied } \\
\text { Systems Analysis. Cambridge and New York, and Laxenburg. }\end{array}$ \\
\hline $\begin{array}{l}\text { Target 6.4. By 2030, substantially increase water-use efficiency across all } \\
\text { sectors and ensure sustainable withdrawals and supply of freshwater to } \\
\text { address water scarcity and substantially reduce the number of people } \\
\text { suffering from water scarcity. }\end{array}$ & $\begin{array}{l}\text { Today, electricity generation uses about eight percent of all freshwater } \\
\text { withdrawals worldwide (notably, for the cooling of thermal plants). } \\
\text { More efficient transformation, distribution and use of energy could } \\
\text { reduce the need for generation, thus lowering water use in the energy } \\
\text { sector. }\end{array}$ & $\begin{array}{l}\text { Scott, C. A., Pierce, S. A., Pasqualetti, M. J., Jones, A. L., Montz, B. E., \& } \\
\text { Hoover, J. H. (2011). Policy and institutional dimensions of the water- } \\
\text { energy nexus. Energy Policy, 39(10), pp. 6622-6630. }\end{array}$ \\
\hline $\begin{array}{l}\text { Target 8.4. Improve progressively, through 2030, global resource } \\
\text { efficiency in consumption and production and endeavour to decouple } \\
\text { economic growth from environmental degradation, in accordance with } \\
\text { the 10-year framework of programmes on sustainable consumption and } \\
\text { production, with developed countries taking the lead. }\end{array}$ & $\begin{array}{l}\text { While economic growth leads to higher levels of energy consumption, } \\
\text { energy conservation has not been shown to impede economic growth. } \\
\text { By reducing fuel-related expenditures, energy efficiency can liberate } \\
\text { capital for use in sustainable economic growth. }\end{array}$ & $\begin{array}{l}\text { GEA (2012). Global Energy Assessment - Toward a Sustainable Future. } \\
\text { Cambridge University Press, and the International Institute for Applied } \\
\text { Systems Analysis. Cambridge and New York, and Laxenburg. }\end{array}$ \\
\hline
\end{tabular}

Source: own elaboration 


\section{References}

Reed, P., Amunategui, I., Alderson, S., Gomelsky, R. Gómez, B., Bernabé, L., Ramírez, S. Aguado, S. \& D'Silva, N. (2015). Energy efficiency policy case studies. DNV-GL. Oslo.

GEA (2012). Global Energy Assessment - Toward a sustainable future. Cambridge University Press, and the International Institute for Applied Systems Analysis. Cambridge and New York, and Laxenburg.

Locke, E. A., Shaw, K. N., Saari, L. M., \& Latham, G. P. (1981). Goal setting and task performance: 1969-1980. Psychological bulletin, 90(1), p. 125.

OECD/IEA (2014). Capturing the multiple benefits of energy efficiency. Organisation for Economic Cooperation and Development / International Energy Agency. Paris.

Puig, D. and Farrell, T. (2014). The multiple benefits of measures to improve energy efficiency. UNEP DTU Partnership. Copenhagen.

UN-DESA (2017). The Sustainable Development Goals Report 2017. United Nations Department of Economic and Social Affairs. New York.

UNEP (2016). The emissions gap report 2016: a UNEP synthesis report. United Nations Environment Programme. Nairobi.

\section{Endnotes}

1 The Sustainable Development Goals (SDGs) lay out a shared vision to 2030 for seventeen key developmental concerns. The indispensable role that energy efficiency gains have to play with regard to achieving SDG7 (affordable and clean energy), and SDG13 (climate action) is uncontroversial. It is now widely acknowledged that energy efficiency gains can also help achieve SDGs that are not directly related to energy, notably SDG2 (ending hunger), SDG3 (ensuring healthy lives), SDG6 (providing water and sanitation), and SDG8 (promoting sustainable economic growth).

2 SDG7 has three energy-related goals. One of these goals is to double the global rate of improvement in energy efficiency by 2030. Progress toward meeting this and the other two energyrelated goals is being tracked at the global, regional and national level through the so-called Global Tracking Framework.

3 The list is based on a survey of twenty-five national programmes affecting energy efficiency (Reed et al. 2015). The survey covered the following types of programmes: building efficiency, carscrapping, demand-side management, financial inducements, performance benchmarking, policy frameworks, standards and labels, and voluntary agreements.

$4 \quad$ The Clean Energy Ministerial is an annual, high-level global forum that brings together leaders of the G20. The objective of these fora is to promote policies and share good practices in the area of cleaner energy.

5 Reflecting this, in 2016 G20 leaders adopted the G20 Energy Efficiency Leading Programme, a "comprehensive, flexible, and adequately-resourced long term framework necessary for strengthened $\mathrm{G} 20$ voluntary collaboration on energy efficiency". 